ISSN 0258-7122

Bangladesh J. Agril. Res. 40(2): 325-332, June 2015

\title{
SUITABILITY STUDY OF LOCAL BUSH BEAN CULTIVARS INTERCROPPED WITH HYBRID MAIZE UNDER DIFFERENT PLANTING SYSTEM IN HILLY AREAS
}

\author{
M. SHAHEENUZZAMN ${ }^{1}$, A. BISWAS ${ }^{2}$, N. CHAKMA ${ }^{3}$ \\ M. N. ISLAM ${ }^{4}$ AND M. SALIM ${ }^{5}$
}

\begin{abstract}
An intercropping experiment was conducted on hill valley at Hill Agricultural Research Station, Ramgarh and Kharachari during two consecutive rabi seasons of 2012-13 and 2013-14 to select suitable local bush bean cultivar for intercropping with hybrid maize in hilly areas of Bangladesh. Seven intercropping treatments viz., $\mathrm{T}_{1}=$ Normal maize spacing $(75 \mathrm{~cm} \times 25 \mathrm{~cm})+2$ rows black seeded bush bean, $\mathrm{T}_{2}=$ Normal maize spacing $(75 \mathrm{~cm} \times 25 \mathrm{~cm})+2$ rows pink seeded bush bean, $\mathrm{T}_{3}=$ Maize wider spacing $(100 \mathrm{~cm} \times 25 \mathrm{~cm})$ with 1 plant $/$ hill +3 rows black seeded bush bean, $\mathrm{T}_{4}=$ Maize wider spacing $(100 \mathrm{~cm} \times$ $25 \mathrm{~cm}$ ) with 1 plant/hill +3 rows pink seeded bush bean, $\mathrm{T}_{5}=$ Maize wider spacing $(100 \mathrm{~cm} \times 50 \mathrm{~cm})$ with 2 plants $/$ hill +3 rows black seeded bush bean, $\mathrm{T}_{6}$ $=$ Maize wider spacing $(100 \mathrm{~cm} \times 50 \mathrm{~cm})$ with 2 plants $/$ hill +3 rows pink seeded bush bean and $\mathrm{T}_{7}=$ Sole maize spacing $(75 \mathrm{~cm} \times 25 \mathrm{~cm})$ were used. Sole hybrid maize produced the highest grain yield at both the locations. Bush bean cultivars in intercropped situation depressed hybrid maize yields by $7.15-37.29 \%$ at Ramgarh and $2.56-37.51 \%$ at Khagrachari compared to sole hybrid maize. The highest maize equivalent yield of $23.10 \mathrm{t} / \mathrm{ha}$ at Ramgarh and $24.08 \mathrm{t} / \mathrm{ha}$ at Khagrachari was recorded in maize wider spacing $(100 \mathrm{~cm} \times 25 \mathrm{~cm})$ with 1 plant/hill +3 rows pink seeded bush bean combination $\left(\mathrm{T}_{4}\right)$. The same treatment also showed the highest gross return (Tk 277200/ha at Ramgarh and Tk 288960/ha at Khagrachari), gross margin (Tk 180050/ha at Ramgarh and Tk 191810/ha at Khagrachari) and benefit cost ratio (2.85 at Ramgarh and 2.97 at Khagrachari). The result revealed that maize wider spacing $(100 \mathrm{~cm} \times 25 \mathrm{~cm})$ with 1 plant/hill +3 rows pink seeded bush bean could be suitable and economically profitable for hybrid maize and bush bean intercropping in hill valleys of Bangladesh.
\end{abstract}

Keywords: Suitability, Intercropping, Hybrid maize, Bush bean, Hilly areas.

\section{Introduction}

Intercropping is an excellent technique to increase total productivity (Islam et al., 2010), monetary return (Begum et al., 2010), and resource use efficiency (Islam et al., 2006) as well as to fulfill the diversified need of farmers (Akhteruzzaman

\footnotetext{
${ }^{1}$ Scientific Officer, Agronomy Division, Bangladesh Agricultural Research Institute (BARI), Joydebpur, Gazipur, ${ }^{2}$ Scientific Officer, Regional Agricultural Research Station, Jessore, ${ }^{3}$ Scientific Officer, Hill Agricultural Research Station, Khagrachari and ${ }^{4}$ Principal Scientific Officer, Agronomy Division, BARI, Joydebpur, Gazipur, ${ }^{5}$ Scientific Officer, Hill Agricultural Research Station, BARI, Khagrachari Hill District, Bangladesh.
} 
et al., 2008). The use of early maturing crop varieties, row arrangement, spacing and plant population are some important methods that help to increase the yield of intercrop (Craufard, 2000; Ahmed et al., 2000 and Rahaman et al., 2009). Moreover, by changing planting geometry of tall crop, incident light on the under storey crop canopy may be increased which also accelerate the production.

Evans (2001) reported that cereal-legume intercropping is more productive and profitable cropping system than other intercropping systems. Islam (2002) stated that hybrid maize and bush bean intercropping is competent because of differing in growth duration, demand of nutrient requirement, photosynthetic path way etc. Bush bean cultivars (Black seeded and pink seeded) are very popular to tribes and they grow those in hilly areas as sole crop. Green seeds of bush bean are preferable to them. Similarly, the hill farmers also grow hybrid maize as sole crop. Possibility of increasing production of these two crops by increasing area under cultivation is limited. So, intercropping is the only way to enhance production of those crops. Therefore, this experiment was conducted to find out the local bush bean cultivars suitable for intercropping with hybrid maize under different planting systems.

\section{Materials and Method}

The experiment was conducted on hill valley at Hill Agricultural Research Station, Ramgarh and Khagrachari during two consecutive rabi seasons of 201213 and 2013-14. The soil of the experimental field of Khagrachari was clay loam in texture with $\mathrm{pH} 4.6$, medium in organic matter $(2.51 \%)$, low in total nitrogen $(0.132 \%)$, very high in phosphorus $(34 \mu \mathrm{g} / \mathrm{g})$, low in potassium $(0.12 \mathrm{meq} / 100 \mathrm{~g})$, optimum in sulphur $(29 \mu \mathrm{g} / \mathrm{g})$, medium in zinc $(1.27 \mu \mathrm{g} / \mathrm{g})$ content belonging to Mirersharai series under AEZ-29. On the contrary, the soil of the experimental field of Ramgarh was clay loam in texture with $\mathrm{pH} 4.5$, medium in organic matter $(2.36 \%)$, low in total nitrogen $(0.130 \%)$, very low in phosphorus $(4 \mu \mathrm{g} / \mathrm{g})$, low in potassium $(0.11 \mathrm{meq} / 100 \mathrm{~g})$, low in sulphur $(17 \mu \mathrm{g} / \mathrm{g})$, low in zinc $(0.57 \mu \mathrm{g} / \mathrm{g})$ content belonging to Mirersharai series under AEZ-29. Seven intercropping treatments viz., $\mathrm{T}_{1}=$ Normal maize spacing $(75 \mathrm{~cm} \times 25 \mathrm{~cm})+2$ rows black seeded bush bean, $\mathrm{T}_{2}=$ Normal maize spacing $(75 \mathrm{~cm} \times 25 \mathrm{~cm})+2$ rows pink seeded bush bean, $\mathrm{T}_{3}=$ Maize wider spacing $(100 \mathrm{~cm} \times 25 \mathrm{~cm})$ with 1 plant $/$ hill + 3 rows black seeded bush bean, $\mathrm{T}_{4}=$ Maize wider spacing $(100 \mathrm{~cm} \times 25 \mathrm{~cm})$ with 1 plant $/$ hill +3 rows pink seeded bush bean, $T_{5}=$ Maize wider spacing $(100 \mathrm{~cm} \times$ $50 \mathrm{~cm}$ ) with 2 plants $/$ hill +3 rows black seeded bush bean, $\mathrm{T}_{6}=$ Maize wider spacing $(100 \mathrm{~cm} \times 50 \mathrm{~cm})$ with 2 plants $/$ hill +3 rows pink seeded bush bean and $\mathrm{T}_{7}=$ Sole maize spacing $(75 \mathrm{~cm} \times 25 \mathrm{~cm})$ were used in this study. The experiment was laid out in a randomized complete block design with three replications. The unit plot size was $3 \mathrm{~m} \times 3 \mathrm{~m}$. Hybrid maize (var. BARI Hybrid maize-7) and bush bean cultivars (Black seeded and pink seeded) were used in this experiment. Seed rate of bush bean was considered as $36 \mathrm{~kg} / \mathrm{ha}$. Seeds of maize and bush bean were sown on 24 November 2012 and 25 November 2013 
in both the location according to treatments. Sole hybrid maize and intercrop was grown with 250-55-110-40-4-2 kg/ha of NPKSZnB (FRG, 2012). Fifty percent N and full amount of all other fertilizers were applied as basal. Remaining $\mathrm{N}$ was applied as top dressing at 30 days after sowing (DAS). Two irrigations were given at 30 and 60 DAS. Other intercultural operations were done as and when required. Plant population of both the crops was taken in linear metre from randomly selected 3 places in each plot and converted to plants $/ \mathrm{m}^{2}$. Data on yield components of maize and bush bean were taken from randomly selected 5 plants from each plot. Hybrid maize was harvested at 150 DAS in both years and locations. Harvesting of bush bean pods was started from 100 DAS and continued up to 110 DAS in both years and locations. The mean comparisons were done by using Least Significant Difference (LSD) test. Cost of land preparation, seeds, fertilizers, labour for different operations and irrigation etc. were considered as production cost. Benefit cost analysis was also done. Maize equivalent yield was computed by converting the yield of intercrops on the basis of prevailing market price of both the crops following the formula of Bandyopadhyay (1984).

Maize equivalent yield $($ MEY $)=\mathrm{Yim}+\frac{\mathrm{Yib} \times \mathrm{Pb}}{\mathrm{Pm}}$

Where, Yim= yield of intercrop maize (t/ha)

$\mathrm{Yib}=$ yield of intercrop bush bean $(\mathrm{t} / \mathrm{ha})$

$\mathrm{Pm}=$ selling price of maize grain $(\mathrm{Tk} / \mathrm{kg})$

$\mathrm{Pb}=$ selling price of bush bean green seed $(\mathrm{Tk} / \mathrm{kg})$

\section{Results and Discussion}

Similar trend was observed in yield and yield attributes in both the years so pooled analysis was done and discussed the results below accordingly.

\section{Effect on maize}

Number of cobs $/ \mathrm{m}^{2}$ and grain yield/ha of hybrid maize were influenced significantly due to intercropping with bush bean under different planting systems at both the locations but number of grains/cob and 1000-grain weight were not significantly affected (Table 1 ). The maximum number of cobs $/ \mathrm{m}^{2}(5.3)$ was recorded in sole maize $\left(T_{7}\right)$ which was at par with $T_{1}$ and $T_{2}$ combinations at both the locations. Identical number of cobs $/ \mathrm{m}^{2}$ in these treatments was attributed to the similar planting system. The minimum number of cobs $/ \mathrm{m}^{2}$ at Ramgarh (3.6) and at Khagrachari (3.7) was found in $T_{6}$ combination and it was statistically identical to $\mathrm{T}_{3}, \mathrm{~T}_{4}$ and $\mathrm{T}_{5}$ combinations. Three rows of bush bean as intercrop in $\mathrm{T}_{5}$ and $\mathrm{T}_{6}$ drastically reduced cobs $/ \mathrm{m}^{2}$ than 2 rows of bush bean by reducing cobs/plant though grains/cob and 1000-grain weight were identical. The 
grain yield of hybrid maize varied from 6.93 to $10.26 \mathrm{t} / \mathrm{ha}$ at Ramgarh and 7.08 to 11.11.04 tha at Khagrachari due to intercropping with bush bean under different planting systems. The maximum grain yields of hybrid maize at Ramgarh (11.05 $\mathrm{t} / \mathrm{ha})$ and at Khagrachari (11.33 t/ha) were obtained from sole maize $\left(\mathrm{T}_{7}\right)$. Higher grain yield of hybrid maize in those combinations were contributed mainly by the number of cobs $/ \mathrm{m}^{2}$. In the rest treatments grain yield of hybrid maize were statistically lower (6.93-7.81 t/ha) at Ramgarh and (7.08-7.89 t/ha) at Khagrachari. The results indicated that intercropping reduced grain yield of hybrid maize (7.15-37.29\% at Ramgarh and $2.56-37.51 \%$ at Khagrachari) compared to sole maize. Minimum grain yield reduction was observed in treatment $\mathrm{T}_{1}$ and $\mathrm{T}_{2}$ whereas maximum in $\mathrm{T}_{6}$. Similar results were reported by Islam et al. (2004) in maize-bush bean intercropping systems.

Table 1. Grain yield and yield components of hybrid maize in maize-bush bean intercropping under different planting systems at Ramgarh and Khagrachari (pooled of 2012-13 and 2013-14).

\begin{tabular}{|c|c|c|c|c|c|c|c|c|}
\hline \multirow[t]{2}{*}{ Treatment } & \multicolumn{2}{|c|}{ Cobs/m $/ \mathbf{m}^{2}$ (no.) } & \multicolumn{2}{|c|}{ Grains/cob (no.) } & \multicolumn{2}{|c|}{$\begin{array}{c}\text { 1000-grain wt. } \\
\text { (g) }\end{array}$} & \multicolumn{2}{|c|}{$\begin{array}{c}\text { Grain yield } \\
\text { (t/ha) }\end{array}$} \\
\hline & Ram & Kha & Ram & Kha & Ram & Kha & Ram & Kha \\
\hline $\mathrm{T}_{1}$ & 5.2 & 5.3 & 547.1 & 562.5 & 360.5 & 370.3 & 10.26 & 11.04 \\
\hline $\mathrm{T}_{2}$ & 5.1 & 5.2 & 517.2 & 549.5 & 350.7 & 360.0 & 10.19 & 11.00 \\
\hline $\mathrm{T}_{3}$ & 3.8 & 3.9 & 543.2 & 550.7 & 370.0 & 380.1 & 7.64 & 7.69 \\
\hline $\mathrm{T}_{4}$ & 3.8 & 3.9 & 550.9 & 550.0 & 360.5 & 377.2 & 7.81 & 7.89 \\
\hline $\mathrm{T}_{5}$ & 3.8 & 3.8 & 543.8 & 535.0 & 360.0 & 370.4 & 7.44 & 7.53 \\
\hline $\mathrm{T}_{6}$ & 3.6 & 3.7 & 550.2 & 530.5 & 350.0 & 360.7 & 6.93 & 7.08 \\
\hline $\mathrm{T}_{7}$ & 5.3 & 5.3 & 548.1 & 540.5 & 380.5 & 395.5 & 11.05 & 11.33 \\
\hline $\operatorname{LSD}_{(0.05)}$ & 0.3 & 0.8 & NS & NS & NS & NS & 3.10 & 3.31 \\
\hline $\mathrm{CV}(\%)$ & 4.2 & 8.8 & 9.1 & 10.3 & 8.0 & 3.9 & 7.8 & 11.0 \\
\hline
\end{tabular}

NS: Not significant, Ram: Ramgarh and Kha: Khagrachari

$\mathrm{T}_{1}=$ Normal maize spacing $(75 \mathrm{~cm} \times 25 \mathrm{~cm})+2$ rows black seeded bush bean, $\mathrm{T}_{2}=$ Normal maize spacing $(75 \mathrm{~cm} \times 25 \mathrm{~cm})+2$ rows pink seeded bush bean, $\mathrm{T}_{3}=$ Maize wider spacing $(100 \mathrm{~cm} \times 25 \mathrm{~cm})$ with 1 plant/hill +3 rows black seeded bush bean, $\mathrm{T}_{4}=$ Maize wider spacing $(100 \mathrm{~cm} \times 25 \mathrm{~cm})$ with 1 plant $/$ hill +3 rows pink seeded bush bean, $\mathrm{T}_{5}=$ Maize wider spacing $(100 \mathrm{~cm} \times 50 \mathrm{~cm})$ with 2 plants/hill +3 rows black seeded bush bean, $\mathrm{T}_{6}=$ Maize wider spacing $(100 \mathrm{~cm} \times 50 \mathrm{~cm})$ with 2 plants $/$ hill +3 rows pink seeded bush bean and $\mathrm{T}_{7}=$ Sole maize spacing $(75 \mathrm{~cm} \times 25 \mathrm{~cm})$.

\section{Effect on Bush bean}

Only green seed yield/ha of bush bean was varied significantly in hybrid maize bush bean intercropping under different planting systems at both the locations. Number of plants $/ \mathrm{m}^{2}$, green pods/plant, green seeds/pod and 100-green seed weight did not differ significantly among the treatments at both the locations (Table 2). Maximum green seed yield (9.17 t/ha at Ramgarh and $9.71 \mathrm{t} / \mathrm{ha}$ at Khagrachari) were recorded in $\mathrm{T}_{4}$ combination which was identical with $\mathrm{T}_{6}$ 


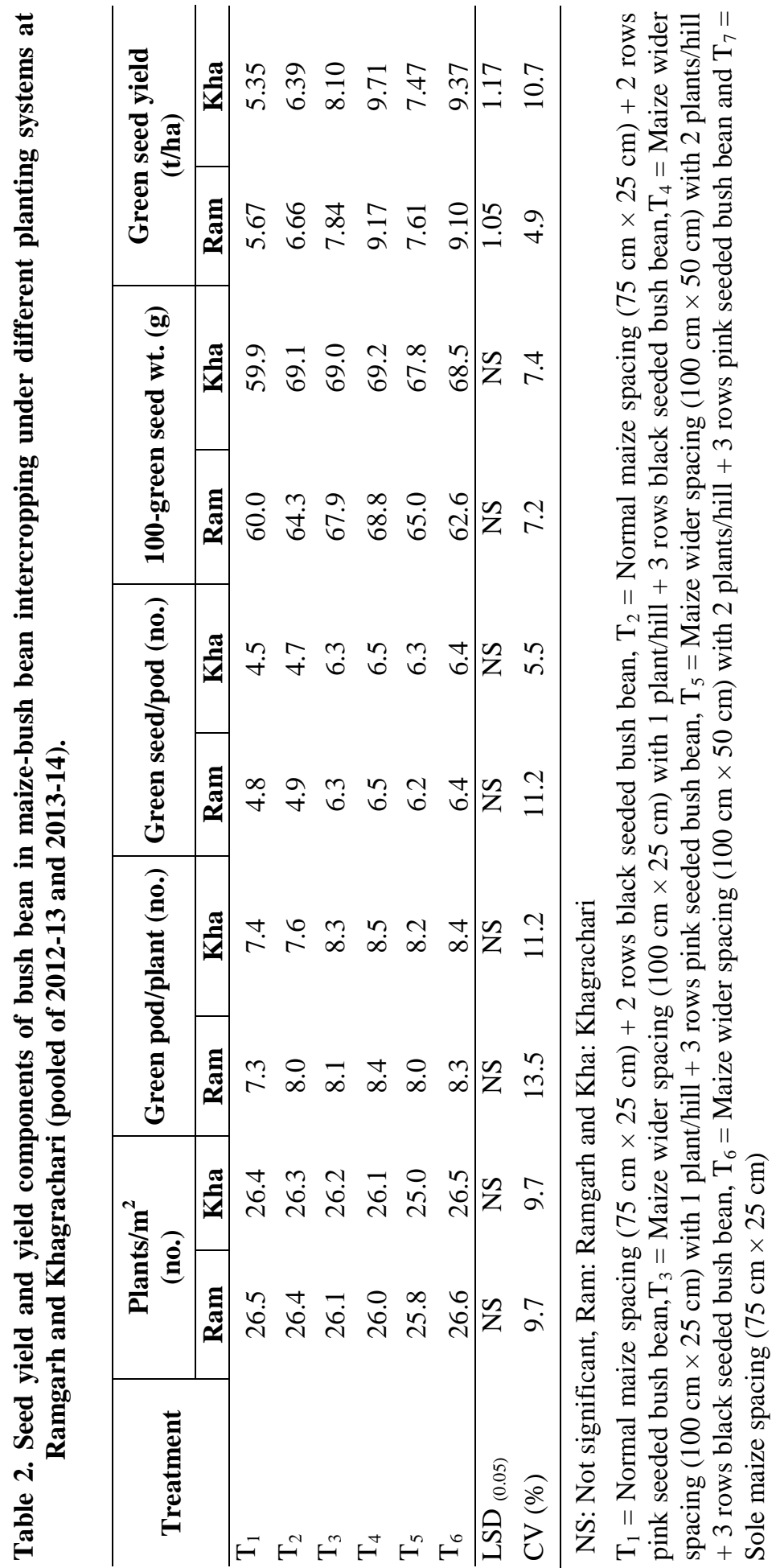


330

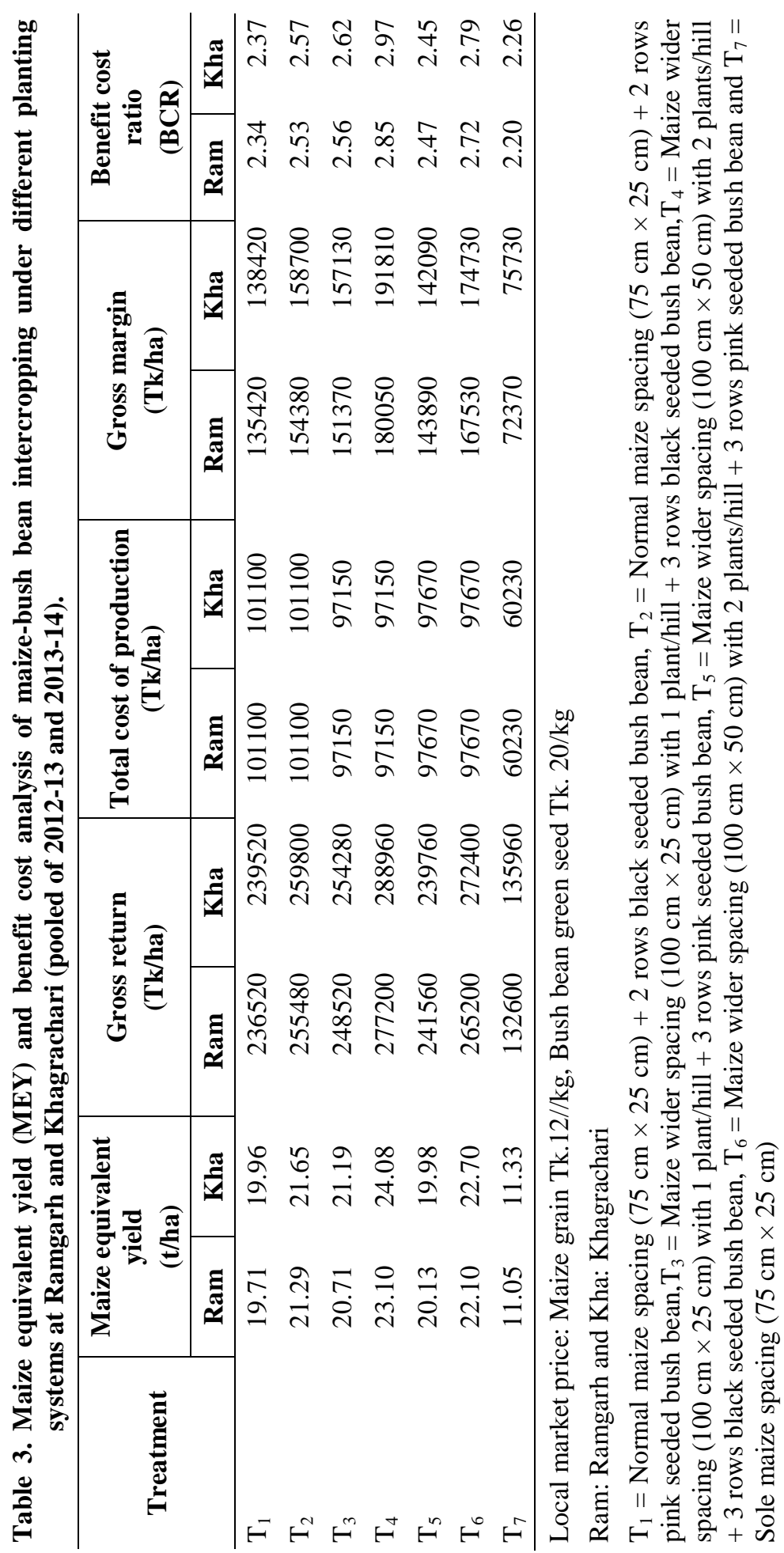

은

.$+ \frac{N}{2}$ ส

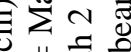

4.

$x=1$ 政

요

ज $\times$

으를 즐

更

는

年的

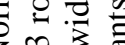

+ + 造

$\rightarrow \sum \sum$

ฮํㅠㄹ

可㻤

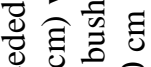

次 8

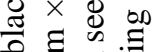

है०

$\checkmark=\sum_{0}^{\infty}$

की + त्र

i $\overline{0}$

영 हี जิ כ

SHAHEENUZZAMN et al. 
combination. Higher green seed yields in those combinations were attributed to the cumulative effect of yield components. Similar results were reported by Ahmed et al. (2006) in maize/spinach-red amaranth intercropping. The results indicated that number of pod/plant, seed/pod, seed size and green seed yield of bush bean was influenced by planting systems of hybrid maize. The values of these parameters were more in wider spacing of hybrid maize might be for availability of more light on bush bean canopy. When two maize plants/hill were maintained, those values were reduced slightly probably for less light availability. On the contrary, pink seeded bush bean cultivar was superior to black seeded one in respect of pods/plant, seeds/pod, seed size and seed yield.

\section{Intercrop efficiency}

Maize equivalent yield (MEY) and benefit cost analyses are presented in Table 3. All the intercrop combinations produced much higher MEY over sole hybrid maize. Among those, the highest MEY (23.10 t/ha at Ramgarh and 24.08 t/ha at Khagrachari) was recorded in $T_{4}$ combination which was followed by $T_{6}$ combination (22.10 t/ha at Ramgarh and $22.70 \mathrm{t} / \mathrm{ha}$ at Khagrachari). Maximum MEY in aforesaid combination was observed due to additional seed yield of bush bean without affecting the grain yield of maize.

The highest gross return (Tk. 277200/ha at Ramgarh and Tk. 288960/ha at Khagrachari) was obtained from $\mathrm{T}_{4}$ combination at both the locations which was close to $\mathrm{T}_{6}$ combination (Tk. 265200/ha at Ramgarh and Tk. 272400/ha at Khagrachari). Higher gross return in these combinations was contributed by the higher MEY. Cost of production of all intercropping systems was more than sole hybrid maize because of the involvement of higher seed cost as well as cost of more labours engaged in different operations. The highest gross margin (Tk. 180050/ha at Ramgarh and Tk. 191810/ha at Khagrachari) was found from $\mathrm{T}_{4}$ combination at both the locations which was very close to $\mathrm{T}_{6}$ combination (Tk. 167530/ha at Ramgarh and Tk. 174730/ha at Khagrachari) owing to higher gross returns and lower cost of production than $\mathrm{T}_{1}$ and $\mathrm{T}_{2}$. The highest benefit cost ratio (2.85 at Ramgarh and 2.97 at Khagrachari) was also recorded in $\mathrm{T}_{4}$ combination at both the locations and it was close to $\mathrm{T}_{6}$ combination (2.72 at Ramgarh and 2.79 at Khagrachari). Uddin et al. (2006) also obtained higher MEY and economic returns from hybrid maize and bush bean intercropping system.

\section{Conclusion}

The results revealed that maize wider spacing $(100 \mathrm{~cm} \times 25 \mathrm{~cm})$ with 1 plant/hill +3 rows pink seeded bush bean might be suitable and economically profitable for hill valleys of Bangladesh. So, the farmers of hilly areas could be suggested to grow pink seeded bush bean cultivar as intercrop with hybrid maize for getting maximum profit. 


\section{References}

Ahmed, F., M. A. Rahaman, M.A.H.S. Jahan, M. Ahmed and M.A. Khayer. 2006. Effect of different planting systems in maize/spinach-red amaranth intercropping. Bangladesh J. Agric. And Environ. 2(2):69-76.

Ahmed, F., T. Haraguchi, O. Hirota and M. A. Rahman. 2000. Growth analysis, yield and canopy structure in maize/ mungbean intercropping. Bull. Inst. Trop. Agr. Kyushu Univ. 23: 61-69.

Akhetruzzaman, M., M. N. Islam, B.L. Nag and M.T. Rahman. 2008. Productivity of potato-hybrid maize relay cropping under different fertilizer levels. Eco-friendly Agril. J. 1(5): 300-303.

Bandyopadhyay, S.N. 1984. Nitrogen and water relations in grain sorghum-legume intercropping systems. Ph. D. Dissertation, Indian Agricultural Research Institute, New Delhi. Pp. 1-195.

Begum, S., M. N. Islam, M.T. Rahaman, J. A. Chowdhury and M. I. Haque. 2010. Suitability study of different chilli varieties for intercropping with sweet gourd. Expt. Biosci. 1 (2):1-4.

Craufard, P. Q. 2000. Effect of plant density on the yield of sorghum- cowpea and pearl millet-cowpea intercrops in northern Nigeria. Expt. Agric. 36: 379-395.

Evans J., A. M. Mcneill, M. J. Unkovich, N.A. Fettell and D. P. Heenan. 2001. Net nitrogen balances for cool-season grain legume intercropping and contributions to wheat nitrogen uptake: a review. Aus. J. Exp. Agric. 41: 347-359.

FRG. 2012. Fertilizer Recommendation Guide, Bangladesh Agricultural Research Council (BARC), Farmgate, Dhaka 1215. 274p.

Islam, M. N. 2002. Competitive interference and productivity in maize-bushbean intercropping system. A Ph.D. Dissertation, Dept. of Agronomy, Bangabandhu Sheikh Mujibur Rahaman Agricultural University, Gazipur. Pp.1-160.

Islam, M. N., M. A.I. Sarker, M.K. Islam, S. Begum and M. A. Mannaf. 2010. Intercropping of brinjal with chilli under different planting geometry for higher productivity and return. J. Expt. Biosci. 1(2):51-55.

Islam, M.N., M. M. Haque and A. Hamid. 2006. Planting arrangement and population density effect on the physiological attributes and productivity of maize-bushbean intercropping system. Bangladesh J. Agril. Res. 31(3):353-364.

Islam, M.N., M.M. Haque and A. Hamid. 2004. Productivity and competitive interference in maize and Bush bean intercropping system in different sowing dates. Bangladesh J. Agril. Res. 29(2): pp. 193.

Rahman, M. T., M. N. Islam, M. I. Ahmed, R. K. Bhuiya and M. R. Islam. 2009. Intercropping mungbean with mukhikachu. Annual Research Report (2009-2010). Agronomy Division, Bangladesh Agricultural Research Institute, Joydebpur, Gazipur-1701. Pp. 89-93.

Uddin, M. J., M. A. Quayyum, M. N. Islam and N. C. Basak. 2006. Intercropping of hybrid maize with bushbean at different fertilizer levels. Bangladesh J. Agric. and Environ. 2(2): 17-32. 